\title{
Giant cell tumors of the tendon sheath in the left hallux ${ }^{*}$
}

\section{Rogerio Nabor Kondo ${ }^{1}$ Jefferson Crespigio ${ }^{1}$}

\author{
Priscila Daiane Pavezzi ${ }^{1}$ \\ Hélio Toshikazu Okamura ${ }^{2}$
}

Dear Editor,

This is a case report of a male patient, 47 years of age, with a one-year history of an asymptomatic nodular mass on the left hallux. The patient reported gradual growth, with a rapid increase in size over the past two months.

The dermatological examination revealed a firm, painless mass, measuring approximately $5 \times 4 \mathrm{~cm}$, on the left hallux (Figures $1 \mathrm{~A}$ and $1 \mathrm{~B})$.

The radiographic examination showed no cortical erosion.

Microscopic examination revealed a lesion predominantly consisting of mononuclear cells and multinucleated giant cells, dispersed in hyalinized collagen fiber bundles. These findings are compatible with giant cell tumors of the tendon sheath (Figures 2 and 3).
The patient underwent tumor wide excision performed by the orthopedist.

Giant cell tumors of the tendon sheath (GCT-TS) are solitary benign tumors that represent the second most common tumor on the hand, after ganglion cysts. However, this type of lesion is rare on the foot. Chassaignac was the first to describe these benign masses in 1852 and referred to them as tendon sheath cancer. Jaffe was the first, in 1941, to describe GCT-TS as tenosynovitis, a non-neoplastic malignant reaction. ${ }^{1}$

Etiopathogenesis of GCT-TS is unknown, but some authors suggest that this disease results from alterations in lipid metabolism, inflammation or other benign neoplastic processes. The possibility of this disease being caused by trauma has been reported in prior literature. ${ }^{1-4}$

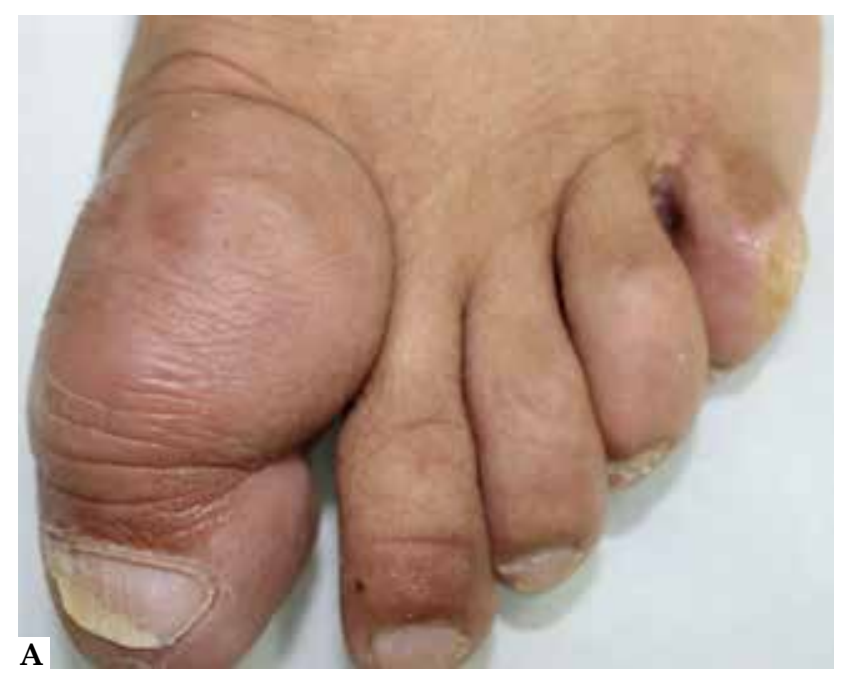

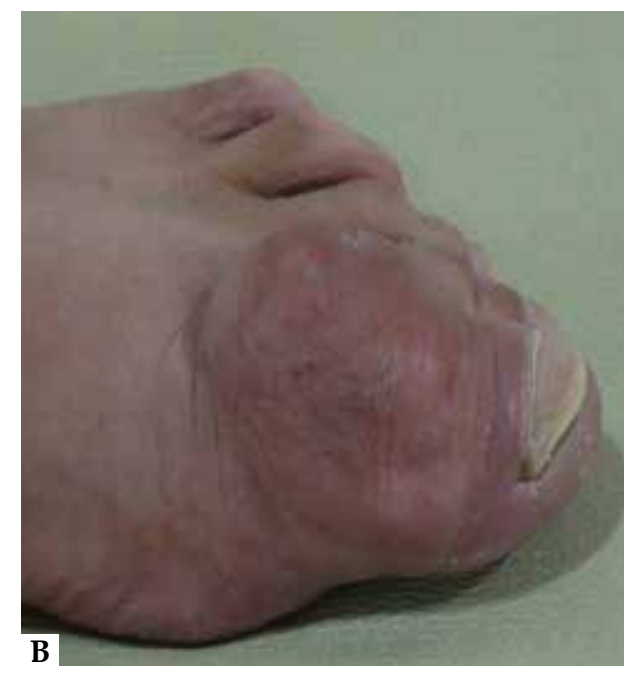

Figure 1:

A. Firm mass on left hallux (front image). B: Medial fact image of left hallux

Received on 06.03.2016

Approved by the Advisory Board and accepted for publication on 08.05.2016

* Work conducted at the Dermatology Clinic of the Northern Paraná Regional University Hospital, Universidade Estadual de Londrina (UEL), Londrina , PR, Brazil.

Financial Support: None.

Conflict of Interest: None.

1 Universidade Estadual de Londrina (UEL), Londrina, PR, Brazil.

Private - Londrina, PR, Brazil.

C2016 by Anais Brasileiros de Dermatologia 


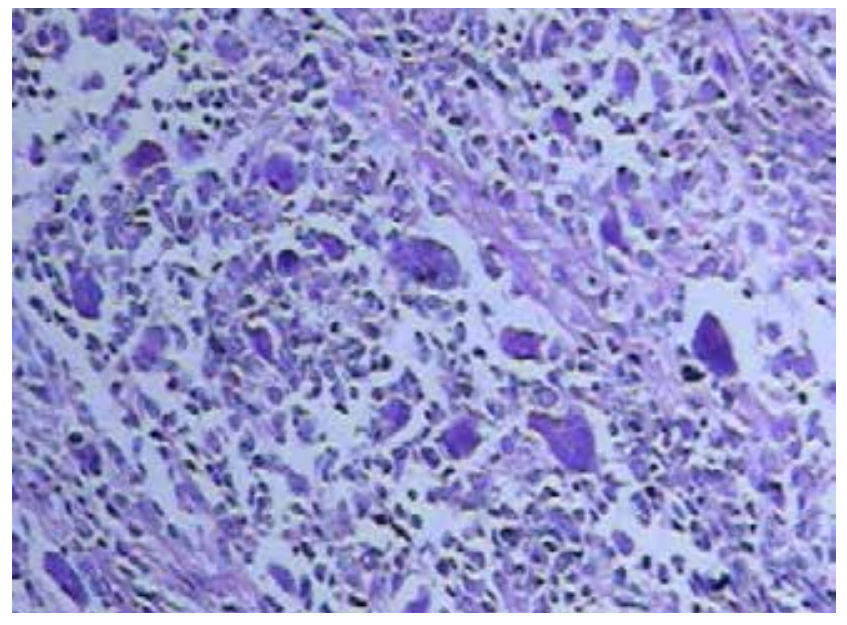

FIGURE 2: Lobed lesion consisting of mononuclear cells, multinucleated giant cells similar to osteoclasts, histiocytes, and lymphocytes. Dense collagenous stroma can be observed (HE 100x)

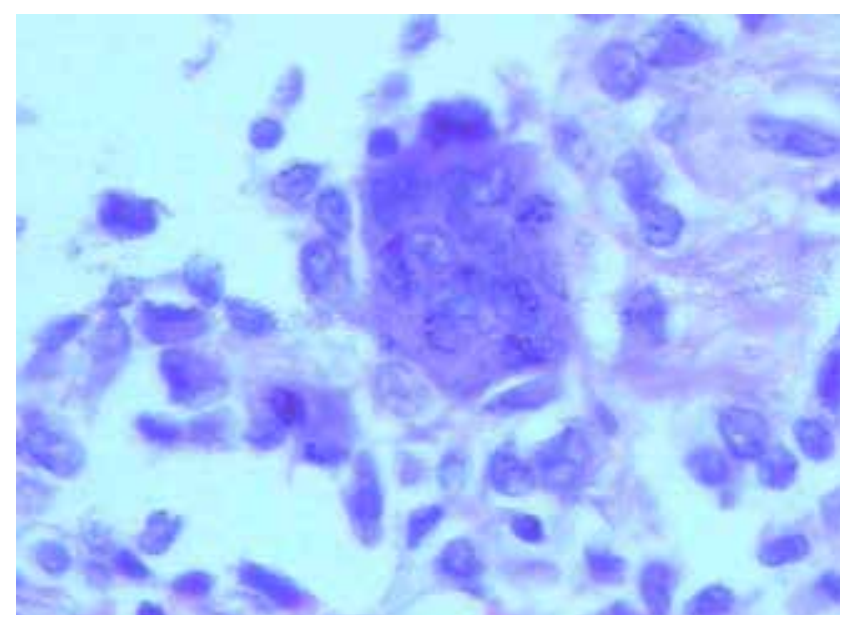

Figure 3: Detail of multinucleated giant cell similar to osteoclast (HE 400x)
Typically, the tumor appears between the third and fifth decades of life, slightly favoring females, at a 2:3 ratio. Lesions are usually local, solitary, appearing as painful or painless subcutaneous nodules. ${ }^{1}$

Radiographs may show whether or not there are erosions under the cortical bone. ${ }^{3,4}$

Histologically speaking, a typical GCT-TS consists of mononuclear cells and multinucleated giant cells spread throughout the hyalinized collagen bundles. Giant cells resemble osteoclasts, microscopically and ultrastructurally, and other smaller cells are stretched and resemble fibroblasts, ${ }^{1}$ as seen in the present case (Figures 2 and 3).

GCT-TS differential diagnoses include: proliferating pilomatricoma, ganglion cysts, pigmented villonodular synovitis, desmoid tumor, glomangioma, and rheumatoid nodule. ${ }^{1-5}$

Preferred treatment is local excision. ${ }^{1-4}$ Tumor relapses have been described in prior literature. ${ }^{2,3}$ Despite being the second most common hand tumor, few GCT-TS cases have been published by dermatologists or found in prior English-language medical literature.]

\section{REFERENCES}

1. Di Grazia S, Succi G, Fragetta F, Perrotta RE. Giant cell tumor of tendon sheath: study of 64 cases and review of literature. G Chir. 2013;34:149-52.

2. Patel AS, Thaker P, Patel R, Ladumore M, Prabhakar MM. A rare case report of giant cell tumor of a tendon sheath. Int J Med Sci Public Health. 2016;5:829-831.

3. Occhipinti E, Heinrich SD, Craver R. Giant cell tumor of tendon sheath arising in the toe. Fetal Pediatr Pathol. 2004;23:171-9.

4. Kuo CL, Yang SW, Chou YJ, Wong CY. Giant cell tumor of the EDL tendon sheath: an unusual cause of hallux valgus. Foot Ankle Int. 2008;29:534-7.

5. Kondo RN, Pontello Junior R, Belinetti FM, Cilião C, Vasconcellos VR, Grimaldi DM. Pilomatricoma proliferante - relato de caso. An Bras Dermatol. 2015;90:94-6.

\author{
MAILING ADDRESS: \\ Rogerio Nabor Kondo \\ Av. Ayrton Senna da Silva, 1055, sala 1205 \\ 86050-460 - Guanabara, Londrina - PR \\ Brazil \\ E-mail: kondo.dermato@gmail.com
}

How to cite this article: Kondo RN, Pavezzi PD, Crespigio J, Okamura HT. Giant cell tumors of the tendon sheath in the left hallux. An Bras Dermatol. 2016;91(5):704-5. 